\title{
Functional Activity of Class-Specific Antibodies to Type III, Group B Streptococcus
}

\author{
JUDITH R. CAMPBELL, CAROL J. BAKER, TERESA G. METZGER, AND \\ MORVEN S. EDWARDS
}

Departments of Pediatrics, Microbiology and Immunology, Baylor College of Medicine, Houston, Texas 77030

\begin{abstract}
The functional activity of naturally acquired IgG and IgM with specificity for the capsular polysaccharide of type III, group B Streptococcus (III-GBS) was compared. Sera collected during convalescence from 14 infants who had developed specific antibodies following III-GBS infection were employed for separation of IgG from IgM by ion-exchange chromatography. Bactericidal killing of III-GBS was similar for IgG- and IgM-rich samples ( 37 and $42 \%$, respectively) in reactions containing a mean of 1.0 or $1.9 \mu \mathrm{g} / \mathrm{ml}$ of III-GBS specific IgG or IgM antibody. Purified IgA lacked opsonophagocytic activity for III-GBS. These results indicate that III-GBS-specific IgG and IgM antibodies in infant sera promote opsonophagocytosis at low concentrations, and that their functional capacity is comparable. (Pediatr Res 23: 31-34, 1988)
\end{abstract}

\section{Abbreviations}

III-GBS, type III, group B Streptococcus

Ig, immunoglobulin

RABA, radioactive antigen-binding assay

RIP, radioimmunoprecipitin

PBS, phosphate-buffered saline

RID, radial immunodiffusion

CFU, colony forming units

QAE, quaternary aminoethyl

Recently, interest has been directed toward the importance of immunoglobulin class in immunity to group B streptococcal infections (1-4). It appears that class specificity of antibodies to III-GBS may influence functional capacity. In comparing the protection provided by class-specific murine monoclonal antibodies in experimental III-GBS infection, Shigeoka et al. (3) found that approximately $100 \mathrm{IgG}$ molecules were required to equal the protective efficacy of one IgM molecule. Although placentally derived antibody in neonates is virtually all $\operatorname{IgG}(5$, 6), Anthony et al. (1) described a striking prevalence of IgM antibody to III-GBS in some adult and maternal sera. These investigators speculated that, if protective, the presence of $\operatorname{lgM}$ antibody might in part explain the infrequent occurrence of invasive III-GBS disease beyond infancy. In an intriguing study, Boyer et al. (7) have suggested that maturation of IgM antibody with specificity for III-GBS during the first 6 months of life might explain the age-limited susceptibility of young infants to GBS infection.

Received February 13, 1987; accepted August 26, 1987.

Correspondence and reprint requests Morven S. Edwards, M.D., Department of Pediatrics, Baylor College of Medicine, One Baylor Plaza, Houston, TX 77030.

Supported in part by Grant AI 19800 from the National Institute of Allergy and Infectious Diseases.
A functional comparison of naturally acquired, class-specific antibodies to III-GBS has been hampered by the lack of a readily available serum source of IgM antibody. We have previously shown that IgM comprises a substantial portion of the III-GBS specific antibody among infants who mount a specific antibody response during convalescence from invasive III-GBS infection (6). With the availability of new methods for separating $\operatorname{IgG}$ from IgM utilizing the small volumes of serum obtainable from infants (8), the present experiments were designed to assess the opsonophagocytic capacity of class-specific antibodies to type III-GBS.

\section{MATERIALS AND METHODS}

Antibody and complement sources. After obtaining parental consent, sera were collected at intervals ranging from 5 days to 3 months after diagnosis in 14 infants recovering from early- or late-onset type III-GBS meningitis (one and 11 infants, respectively) or osteomyelitis (two infants). The infants ranged in age from one to 3.5 months when blood was obtained. The protocol was approved by the Baylor College of Medicine Institutional Review Board for Human Research. Sera were selected from infants who had developed at least $2.0 \mu \mathrm{g} / \mathrm{ml}$ of antibody to type III-GBS by RABA (9), of which at least $20 \%$ was bound by antihuman IgM in the RIP assay (6). Serum from an adult volunteer in whom the majority of specific antibody was bound by antihuman IgG in the RIP was employed for isolation of $\mathrm{IgG}$.

Antibody-deficient sources of complement included agammaglobulinemic serum from a child with severe combined immunodeficiency $(\mathrm{IgG} 10 \mathrm{mg} / \mathrm{dl}$; IgM and IgA undetectable and normal complement levels except Clq, which was 30 to $40 \%$ of normal levels) (10), and sera from a 2 -month-old infant and an adult, each with undetectable $(>0.3 \mu \mathrm{g} / \mathrm{ml})$ antibody to III-GBS by RABA and no opsonophagocytic activity against III-GBS strain, M732. All sera were allowed to clot at room temperature, centrifuged at $4^{\circ} \mathrm{C}$, aliquoted, and stored within $1 \mathrm{~h}$ of collection at $-70^{\circ} \mathrm{C}$.

Chromatographically purified human serum IgA (lot 26499) was obtained from Jackson ImmunoResearch Laboratories, Inc. (West Grove, PA) and from Cappel (lot 5918, Cooper Biomedical, Inc., Malvern, PA). These products contained no preservatives and had demonstrated the appropriate reactivity when assayed by immunoelectrophoresis. Purity was confirmed for each preparation by the lack of detectable IgG or IgM by RID using low concentration plates (LC-Partigen, Calbiochem-Behring, La Jolla, CA). As reconstituted, the two products contained 6.0 and $5.5 \mathrm{mg} / \mathrm{ml}$ total protein and 2.7 and $1.7 \mu \mathrm{g} / \mathrm{ml}$ of IIIGBS specific antibody, respectively, in $0.1 \mathrm{M}$ PBS, pH 7.4.

Separation of $\mathrm{IgG}$ from IgM using small volumes of serum. Small QAE-Sephadex A-50 chromatographic columns (QuikSep IgM Isolation System, Isolab, Inc., Akron, OH) with a bed volume of approximately $6.5 \mathrm{ml}$ were used for immunoglobulin 
separation (8). A 200- $\mu$ l serum sample was diluted 25 -fold in EDTA buffer, pH 7.0, and applied to a column equilibrated in the same buffer. The first $5 \mathrm{ml}$ of IgG-rich eluate containing $\mathrm{IgG}_{1}, \mathrm{IgG}_{2}$, and $\mathrm{IgG}_{3}(8)$ were collected. The column was rinsed extensively with EDTA buffer, the IgM fraction was eluted with $2.5 \mathrm{ml}$ of acetic acid-sodium acetate buffer, $\mathrm{pH} 4.0$, and the $\mathrm{pH}$ of the IgM-rich eluate was neutralized immediately with $2.5 \mathrm{M}$ $\mathrm{NaOH}$. Immunoglobulin subjected briefly to $\mathrm{pH} 4.0$ should retain functional integrity (11). The IgM-rich eluate contained, in addition to $\operatorname{IgM}, \operatorname{IgG}_{4}$, and $\operatorname{IgA}(8)$. The IgG- and IgM-rich samples were then dialyzed against $0.15 \mathrm{M}$ PBS, $\mathrm{pH} 7.4$, and concentrated to their original volume of $200 \mu \mathrm{l}$ in clinical sample concentrators (Minicon B15, Amicon Corp., Danvers, MA).

The concentration of total IgG and IgM in samples was determined by RID with Tri-Partigen kits (Calbiochem-Behring). Low concentration RID plates (LC-Partigen), were used to determine the quantity of IgM remaining in the IgG-rich pools or $\mathrm{IgG}$ remaining in the IgM-rich pools. The concentration of antibody to the type III-GBS capsular polysaccharide in sera and in the IgG and IgM-rich fractions was determined by RABA (9).

Opsonophagocytic assay. The assay used routinely in our laboratory (12) was modified minimally to assess functional activity. Type III-GBS strain, M732, was grown to early log phase in Todd-Hewitt broth, centrifuged, and resuspended in minimal essential medium with Earle's balanced salt solution to approximately $4 \times 10^{7}$ colony forming units $(\mathrm{CFU}) / \mathrm{ml}$. Leukocytes were isolated after sedimentation of peripheral venous blood and were washed and resuspended in minimal essential medium containing $1 \%$ bovine serum albumin to achieve an approximate concentration of $4 \times 10^{7} / \mathrm{ml}$. When required due to small volume, samples were diluted in isotonic, pH 7.5, veronal buffer with $0.1 \%$ gelatin, $0.15 \mathrm{mM} \mathrm{CaCl}_{2}$, and $0.5 \mathrm{mM} \mathrm{MgCl}_{2}$ combined with an equal volume of $0.15 \mathrm{M} \mathrm{NaCl}$.

The reaction mixture consisted of $100 \mu \mathrm{l}$ of an antibody preparation, $50 \mu \mathrm{l}$ each of bacterial suspension $\left(2 \times 10^{6} \mathrm{CFU}\right)$ and neutrophils, and $100 \mu \mathrm{l}$ of antibody-deficient human serum as a complement source. The complement sources had no functional activity for III-GBS in vitro. Each experiment included serum from an adult with high opsonophagocytic activity for IIIGBS. Control tubes lacking either leukocytes, complement, or antibody were included in each assay and these consistently had a bactericidal index of zero. Aliquots of the reaction mixture were removed, diluted, and plated for determination of CFU before and after a 40-min incubation, as described previously (12). The bactericidal index was calculated as the percent reduction in initial inoculum.

\section{RESULTS}

Efficiency of $\operatorname{IgG}$ and $\operatorname{IgM}$ separation. A mean yield of $65 \%$ of initial IgG (range $31-93 \%$ ) and $79 \%$ of initial IgM (range 62$100 \%$ ) were obtained with the small QAE-Sephadex columns (Table 1). IgM in IgG preparations averaged $5.6 \pm 4.0 \%$. A similarly low level of $\operatorname{IgG}(4.0 \pm 1.5 \%)$ was detected in $\operatorname{IgM}$ samples concentrated to the starting volume. The mean III-GBS specific antibody in IgG-rich samples was $11.1 \mu \mathrm{g} / \mathrm{ml}$ (range 1.4$47.7 \mu \mathrm{g} / \mathrm{ml}$ ) and in IgM-rich samples was $6.2 \mu \mathrm{g} / \mathrm{ml}$ (range 1.3$15.8 \mu \mathrm{g} / \mathrm{ml})$.

Functional activity of class-specific antibodies to type III-GBS. Opsonophagocytic activity in samples rich in III-GBS specific $\mathrm{IgG}$ or IgM and for two purified IgA specimens was compared. Among the infant sera processed, the volume was sufficient for testing $11 \mathrm{IgG}$ and nine IgM preparations. In the opsonic reaction mixture, the concentration of IgG III-GBS specific antibody in IgG-rich samples was $1.0 \pm 1.2 \mu \mathrm{g} / \mathrm{ml}$ while that of IgM-rich samples was $1.9 \pm 1.6 \mu \mathrm{g} / \mathrm{ml}$ (Table 2). The bactericidal index for the two groups of samples was not significantly different. Although the bactericidal index did not achieve a level sufficient to provide theoretical "protection" (12), these results indicate that, at low concentrations of specific antibody, the bactericidal capacity of IgG and IgM is similar. In contrast, purified IgA did not promote opsonophagocytic activity.

For some individual IgG- and IgM-rich samples, the volume was sufficient to evaluate a potential dose-response relationship between bactericidal index and the concentration of specific antibody (Table 3). Decline in bactericidal index with dilution was observed for both IgG- and IgM-rich samples. Excluding one IgG-rich sample that exhibited bactericidal activity at extremely low antibody levels, the correlation between the IgG content of IgG-rich samples and bactericidal index was significant $(r=0.864, p>0.01)$. Due perhaps to small numbers, the correlation between IgM content of IgM-rich samples and bactericidal index was less striking $(r=0.429, p=\mathrm{NS})$ even with exclusion of one disparate value.

Serial dilutions using the column-purified IgG and IgM standard sera in serial dilutions are depicted in Table 4. Similarity in bactericidal efficiency and a dose-response relationship is evident. Both of these standard sera were representative of the maximum bactericidal activity observed among the class-specific antibodies in neonatal sera.

\section{DISCUSSION}

Inasmuch as transplacental passage of III-GBS specific IgG antibody in sufficient concentration confers protection against invasive neonatal III-GBS disease, our previous studies and those of others have focused on the opsonic activity of this class of immunoglobulins (13-15). Recently, immunospecific murine monoclonal $\operatorname{IgM}$ antibodies have been viewed with interest as potential immunotherapeutic agents for infants born too prematurely to receive IgG in a theoretically "protective" level (16). The efficacy of murine monoclonal class-specific antibodies for protection in invasive III-GBS experimental infection is well documented $(2,17-18)$. Lack of availability of a suitable source of IgM has previously prevented a functional comparison of naturally acquired class-specific antibodies to type III-GBS.

The experiments described herein indicate that at low concentrations, naturally acquired IgG or IgM with specificity for the capsular polysaccharide of III-GBS have comparable opsonophagocytic activity. For both IgG- and IgM-rich samples, the mean bactericidal index was less than the $90 \%$ value we have previously proposed as a correlate for protection (12). The present experiments were designed to compare functional activity by antibody class in samples that, after purification and in some cases dilution, contained low concentrations of specific antibody. The experimental conditions were intended to allow a comparison of antibody by class rather than to define the concentration which theoretically promotes protective efficacy.

The preceding results must also be qualified in the light of several methodologic aspects unique to the use of human serum as a source of specific antibody. First, polyclonal preparations, by definition, contain large quantities of nonimmunospecific antibodies, whereas monoclonal antibody preparations have a single immunospecificity. It is feasible that the large quantities of nonspecific antibody in our polyclonal preparations participated in phagocytosis which had been initiated by binding of IIIGBS specific antibody $(19,20)$. Second, although the sample preparation method was designed to separate IgG from IgM, absolute purity was not achieved. Thus, despite the technical adequacy of the separation, the specimens were designated as "rich" in the respective predominant immunoglobulin class. However, since class-specific functional activity was similar, the effect of the heterologous class of antibody should not have substantially influenced the results. Finally, the isolation procedure used yielded an IgM pool containing some IgA. Although $\operatorname{IgA}$ is classically considered a nonopsonic class of antibody (21), Egan et al. (18) have shown that type III-specific monoclonal antibody of the IgA class provides protection in a murine mucin model of III-GBS infection. In contrast, the inability of IgA to 
Table 1. Separation of IgG from IgM in 14 infant sera

\begin{tabular}{|c|c|c|c|c|}
\hline Pool & $\begin{array}{c}\text { Mean (range) } \\
\text { immunoglobulin } \\
(\mathrm{mg} / \mathrm{dl})\end{array}$ & $\begin{array}{l}\text { Mean } \\
\text { (range) } \\
\% \text { yield }\end{array}$ & $\begin{array}{c}\% \pm \mathrm{SD} \\
\text { contamination } \\
\text { with heterologous } \\
\text { immunoglobulin* }\end{array}$ & $\begin{array}{c}\text { Mean (range) } \\
\text { III-GBS } \\
\text { antibody } \\
\text { level } \\
(\mu \mathrm{g} / \mathrm{ml})\end{array}$ \\
\hline IgG rich & $\begin{array}{l}483 \\
(217-783)\end{array}$ & $\begin{array}{l}65 \\
(31-93)\end{array}$ & $5.6 \pm 4.0$ & $\begin{array}{l}11.1 \\
(1.4-47.7)\end{array}$ \\
\hline IgM rich & $\begin{array}{l}85 \\
(48-143)\end{array}$ & $\begin{array}{l}79 \\
(62-100)\end{array}$ & $4.0 \pm 1.5$ & $\begin{array}{l}6.2 \\
(1.3-15.8)\end{array}$ \\
\hline
\end{tabular}

* Based upon original serum concentration.

Table 2. Opsonophagocytic activity of class-specific antibodies to $I I I-G B S$

\begin{tabular}{cccc}
$\begin{array}{c}\text { Predominant } \\
\text { antibody } \\
\text { class }\end{array}$ & $\begin{array}{c}\text { No. } \\
\text { samples } \\
\text { tested }\end{array}$ & $\begin{array}{c}\text { Mean } \pm \text { SD III- } \\
\text { GBS antibody } \\
(\mu \mathrm{g} / \mathrm{ml})\end{array}$ & $\begin{array}{c}\text { Mean } \pm \text { SD } \\
\text { bactericidal } \\
\text { index }(\%)\end{array}$ \\
\hline IgG & 11 & $1.0 \pm 1.2$ & $37 \pm 32^{*}$ \\
IgM & 9 & $1.9 \pm 1.6$ & $42 \pm 30^{*}$ \\
IgA & 2 & 0.7 & 0
\end{tabular}

${ }^{*} t=0.3, p=\mathrm{NS}$, unpaired $t$ test.

Table 3. Relationship between bactericidal index and concentration of class-specific antibodies

\begin{tabular}{|c|c|c|c|}
\hline Specimen & $\begin{array}{l}\text { Predominant } \\
\text { antibody class }\end{array}$ & $\begin{array}{c}\text { III-GBS antibody } \\
\text { concentration }(\mu \mathrm{g} / \mathrm{ml}) \\
\text { in reaction mixture }\end{array}$ & $\begin{array}{c}\text { Bactericidal } \\
\text { index }(\%)\end{array}$ \\
\hline \multirow[t]{3}{*}{1} & IgG & 1.3 & 44 \\
\hline & & 0.7 & 31 \\
\hline & & 0.3 & 0 \\
\hline \multirow[t]{2}{*}{2} & $\mathrm{IgG}$ & 1.5 & 56 \\
\hline & & 0.7 & 0 \\
\hline \multirow[t]{3}{*}{3} & IgG & 0.22 & 60 \\
\hline & & 0.12 & 26 \\
\hline & & 0.06 & 0 \\
\hline \multirow[t]{4}{*}{4} & $\mathrm{IgG}$ & 4.2 & 94 \\
\hline & & 2.1 & 85 \\
\hline & & 1.0 & 84 \\
\hline & & 0.5 & 65 \\
\hline \multirow[t]{3}{*}{5} & IgM & 0.8 & 58 \\
\hline & & 0.4 & 31 \\
\hline & & 0.2 & 0 \\
\hline \multirow[t]{3}{*}{6} & IgM & 1.5 & 21 \\
\hline & & 0.7 & 0 \\
\hline & & 0.4 & 0 \\
\hline
\end{tabular}

protect against systemic infection in a neonatal rat model was attributed to its capacity to delay invasiveness of GBS without decreasing their viability (4). Antibodies of the IgA class do contribute to the total III-GBS antibody detected by RABA and can be elicited in response to III-GBS infection (6). The contribution by total IgA in the samples used for the present studies was considered of minimal consequence since $\operatorname{IgA}$ levels in infants less than four months of age are only 10 to $12 \%$ of adult normal levels (22). Furthermore, purified IgA containing IIIGBS antibody had no opsonophagocytic capacity. However, the quantitative detection of functionally inactive IgA in our IgM-
Table 4. Opsonophagocytic assays using column-purified standard sera in serial dilutions

\begin{tabular}{|c|c|c|}
\hline \multirow[b]{2}{*}{ Reciprocal dilution } & \multicolumn{2}{|c|}{$\begin{array}{c}\% \text { Bactericidal index } \\
(\mu \mathrm{g} / \mathrm{ml} \text { III-GBS antibody } \\
\text { in reaction })\end{array}$} \\
\hline & $\mathrm{IgG}$ & IgM \\
\hline 1 & $92(5.8)$ & \\
\hline 2 & & $92(2.6)$ \\
\hline 4 & $87(1.4)$ & $95(1.3)$ \\
\hline 8 & & $93(0.7)$ \\
\hline 16 & $91(0.4)$ & $96(0.3)$ \\
\hline 32 & $89(0.2)$ & $90(0.16)$ \\
\hline 64 & $78(0.1)$ & $83(0.08)$ \\
\hline 128 & $67(0.05)$ & $74(0.04)$ \\
\hline 256 & $60(0.02)$ & $22(0.02)$ \\
\hline 512 & $5(0.01)$ & $4(0.01)$ \\
\hline
\end{tabular}

rich samples could have led to our underestimating the functional capacity of specific IgM.

The finding that naturally acquired, polyclonal $\operatorname{IgG}$ and $\operatorname{IgM}$ antibodies to type III-GBS each are active opsonically and that neither class is clearly superior functionally has potential implications for strategies of disease prevention by passive immunotherapy. IgG modified for intravenous use is now available and infusion of a sufficient amount may provide an adjunct to standard therapy for GBS infant disease. Since III-GBS levels in most of these preparations are modest $(23,24)$ it might be prudent to develop suitable hyperimmune preparations. Either a hyperimmune human immunoglobulin preparation or a standard immune globulin in sufficient amount would circumvent the potential immunological toxicities inherent in monoclonal preparations from heterologous species until such time as humanhuman monoclonals with III-GBS specificity become available.

Acknowledgments. The authors gratefully acknowledge Ms. Robin Dudley and Ms. Marcia Rench for preparation of the manuscript.

\section{REFERENCES}

1. Anthony BF, Concepcion NF, Wass CA, Heiner DC 1984 Immunoglobulin G and $\mathrm{M}$ composition of naturally occurring antibody to type III, group $\mathrm{B}$ streptococci. Infect Immun 46:98-104

2. Shigeoka AO, Jensen CL, Pincus SH, Hill HR 1984 Absolute requirement for complement in monoclonal IgM antibody-mediated protection against experimental infection with type III, group B streptococci. J Infect Dis 150:6370

3. Shigeoka AO, Pritchard DG, Pincus SH, Rote NS, Gray BM, Hill HR 1983 Protective efficacy of $\mathrm{IgM}$, IgG and IgA monoclonal antibodies against experimental systemic or respiratory group B streptococcal (GBS) infection. In: Program and abstracts of the 23rd Interscience Conference on Antimicrobial Agents and Chemotherapy. Washington, D.C.: American Society for Microbiology, (abstr 612)

4. Shigeoka AO, Weber ME, Pincus SH, Pritchard DG, Egan ML, Hill HR 1986 Type-specific monoclonal antibody enhances the local phagocytic response to group B streptococcal infection. J Infect Dis 153:1170-1173

5. Baker CJ, Kasper DL, Tager IB, Paredes A, Alpert S, McCormack WM, Goroff 
D 1977 Quantitative determination of antibody to capsular polysaccharide in infection with type III strains of group B Streptococcus. J Clin Invest 59:810-818

6. Edwards MS, Fuselier PA, Rench MA, Kasper DL, Baker CJ 1984 Class specificity of naturally acquired and vaccine-induced antibody to type III group B streptococcal capsular polysaccharide: Determination with a radioimmunoprecipitin assay. Infect Immun 44:257-261

7. Boyer KM, Papierniak CK, Klegerman ME, Rauen ME, Gotoff SP 1987 Development of IgM antibody to group B Streptococcus (GBS) type III in human infants. Pediatr Res 21:413A(abstr 1436)

8. Johnson RB Jr, Libby R 1980 Separation of immunoglobulin M (IgM) essentially free of $\mathrm{IgG}$ from serum for use in systems requiring assay of IgM-type antibodies without interference from rheumatoid factor. $J$ Clin Microbiol $12: 451-454$

9. Baker CJ, Kasper DL 1976 Correlation of maternal antibody deficiency with susceptibility to neonatal group B streptococcal infection. N Engl J Med 294:753-756

10. Edwards MS, Nicholson-Weller A, Baker CJ, Kasper DL 1980 The role of specific antibody in alternative complement pathway-mediated opsonophagocytosis of type III, group B Streptococcus. J Exp Med 151:1275-1287

11. Römer J, Morgenthaler J-J, Scherz R, Skvaril F 1982 Characterization of various immunoglobulin preparations for intravenous application. Vox Sang 42:62-73

12. Edwards MS, Baker CJ, Kasper DL 1979 Opsonic specificity of human antibody to the type III polysaccharide of group B Streptococcus. J Infect Dis 140:1004-1008

13. Baker CJ, Edwards MS, Kasper DL 1981 Role of antibody to native type III polysaccharide of group B Streptococcus in infant infection. Pediatrics 68:544-549

14. Hemming VG, Hall RT, Rhodes PG, Shigeoka AO, Hill HR 1976 Assessment of group $B$ streptococcal opsonins in human and rabbit serum by neutrophil chemiluminescence. J Clin Invest 58:1379-1387
15. Shigeoka AO, Hall RT, Hemming VG, Allred CD, Hill HR 1978 Role of antibody and complement in opsonization of group B streptococci. Infect Immun 21:34-40

16. Boyer KM, Papierniak CK, Gadzala CA, Parvin JD, Gotoff SP 1984 Transplacental passage of $\mathrm{IgG}$ antibody to group B streptococcus serotype Ia. J Pediatr 104:618-620

17. Christensen RD, Rothstein G, Hill HR, Pincus SH 1984 Treatment of experimental group B streptococcal infection with hybridoma antibody. Pediatr Res 18:1093-1096

18. Egan ML, Pritchard DG, Dillon HC Jr, Gray BM 1983 Protection of mice! from experimental infection with type III, group B Streptococcus using monoclonal antibodies. J Exp Med 158:1006-1011

19. van Oss CJ, Stinson ME 1970 Immunoglobulins as aspecific opsonins. I. The influence of polyclonal and monoclonal immunoglobulins in the in vitro phagocytosis of latex particles and staphylococci by human neutrophils. J Reticuloendothel Soc 8:397

20. Stinson MW, van Oss CJ 1971 Immunoglobulins as aspecific opsonins. II. The influence of specific and aspecific immunoglobulins on the in vitro phagocytosis of nonencapsulated, capsulated and decapsulated bacteria by human neutrophils. J Reticuloendothel Soc 9:503

21. Stiehm ER 1980 The B-lymphocyte system. In: Stiehm ER, Fulginiti VA (eds) Immunologic Disorders in Infants and Children. WB Saunders Co, Philadelphia, pp 20-35

22. Stiehm ER 1980 Immunodeficiency disorders-general considerations. In: Stiehm ER, Fulginiti VA (eds) Immunologic Disorders in Infants and Children. WB Saunders Co, Philadelphia, pp 183-218

23. Givner LB, Edwards MS, Anderson DC, Baker CJ 1985 Enhancement of opsonophagocytosis of neonatal sera with the addition of immune globulin for intravenous use in vitro. J Infect Dis 151:217-220

24. Kim KS, Wass CA, Kang JH, Anthony BF 1986 Functional activities of various preparations of human intravenous globulin against type III group B Streptococcus. J Infect Dis 153:1092-1097 